\title{
ПРИРООНИЧO-ГЕОГРАФ/ИHI DOCЛIOKEHHЯ
}

УДК 551.580:(477)

Л.С. Рибченко, С.В. Савчук

РАДІАЦІЙНИЙ РЕЖИМ В УМОВАХ ІНТЕНСИВНИХ ЗАСУХ 2001-2010 рр. В УКРАÏHI

\author{
Л.С. Рыбченко, С.В. Савчук \\ РАДИАЦИОННЫЙ РЕЖИМ В УСЛОВИЯХ ИНТЕНСИВНЫХ ЗАСУХ 2001-2010 г2. В УКРАИНЕ \\ Украинский научно-исследовательский гидрометеорологический институт, Киев
}

Показаны изменения составляющих радиационного режима в периоды интенсивных засух 2001-2010 гг. относительно стандартной климатологической нормы 1961-1990 гг. Аномалия составляющих радиационного режима в этих условиях наблюдалась по всей территории в отдельные месяцы весны, лета и осени в течение вегетационного периода. Существенное увеличение продолжительности солнечного сияния и прямой солнечной радиации при одновременном уменьшении рассеянной не способствовали интенсивному росту суммарной радиации. Часто в весеннюю и осеннюю засуху нагревание оголенной почвы приводило к росту альбедо подстилающей поверхности. В засушливые периоды отмечалось возрастание радиационного баланса. Проведенные исследования имеют важное значение для мониторинга изменений климатических условий, а также для решения прикладных вопросов адаптации земледелия к этим изменениям.

Ключевые слова: солнечная радиация; радиационный режим; интенсивная засуха; климатологическая норма.

\section{Rybchenko, S.Savchuk \\ RADIATION STATE UNDER THE CONDITION OF INTENSE DROUGHTS 2001 - 2010 yrs. IN UKRAINE \\ Ukrainian hydrometeorological research institute, Kyiv}

Variations of radiation level components during the 2001 - 2010 yrs. intense drought periods relative to the climatological norm 1961 - 1990 yrs. has been demonstrated. Anomaly of the radiation level components in those conditions had been seen throughout entire territory during spring, summer and autumn months of the vegetation period. Significant increase in daylight and direct solar radiation along with decrease in its diffused component did not lead to a fast increase in combined total radiation. During spring and autumn droughts heating of the exposed soil surface often led to the underlying layer albedo. During the periods of drought there had been an increase in radiation levels. The conducted research has a significant importance for climate change monitoring as well as for practical applications in finding the ways to adapt farming to those changes.Keywords: solar radiation; radiation regime; intensive drought; climatological norm.

Key words: solar radiation; radiation conditions; intensive drought; climatological norm.

Засуха є складним природним явищем, зумовленим тривалим періодом збільшеної прямої сонячної радіації й температури повітря, нестачі вологи у повітрі та грунті, що створюють несприятливі умови розвитку сільськогосподарських рослин. Пошкодження і загибель рослин відбуваються внаслідок значного неузгодження потреби вологи в повітрі та грунті за підвищеної інсоляції й термічного режиму.

Результатам дослідження засух на території країни присвячено ряд робіт, що оцінюють ступінь засушливості окремих періодів вегетації, вплив цих умов на стан сільськогосподарських рослин, причини їх виникнення та зміни метеорологічних величин відносно середніх значень [1-8].

В умовах засухи збільшуються енергетичні можливості підстильної поверхні внаслідок значної повторюваності ясної й малохмарної погоди, що призводить до підвищення потоку короткохвильової радіації та перерозподілу енергії між складовими сумарної радіації й радіаційного балансу. Відбувається зростання тривалості сонячного сяйва.

Згідно каталогу за 2001-2010 рр. засухи різної інтенсивності й тривалості на території країни спостерігались впродовж кожного вегетаційного періоду. Визначено види засух (повітряна, грунтова, комплексна повітряно-грунтова), розповсюдження по території, характеристику засушливих явищ 3 перевищенням середніх кліматологічних величин температури повітря і грунту та нестачі вологи, заподіяну шкоду для виробництва сільськогосподарських культур. Розраховано критерії інтенсивності засух, що призводили до різного ступеня перетворення складових радіаційного режиму порівняно із середніми величинами. Побудовано карти складових радіаційного режиму та відхилення тривалості сонячного сяйва, прямої сонячної радіації й альбедо підстильної поверхні відносно кліматологічної стандартної норми в окремі періоди інтенсивної засухи.

Метою виконаних досліджень є оцінювання змін радіаційного режиму в умовах періодів інтенсивної засухи 2001-2010 рр. відносно кліматологічної стандартної норми 1961-1990 рр.

За перше десятиріччя XXI ст. повітряні або повітряно-грунтові засухи різної інтенсивності 7 років 310 охоплювали більшу частину території. 


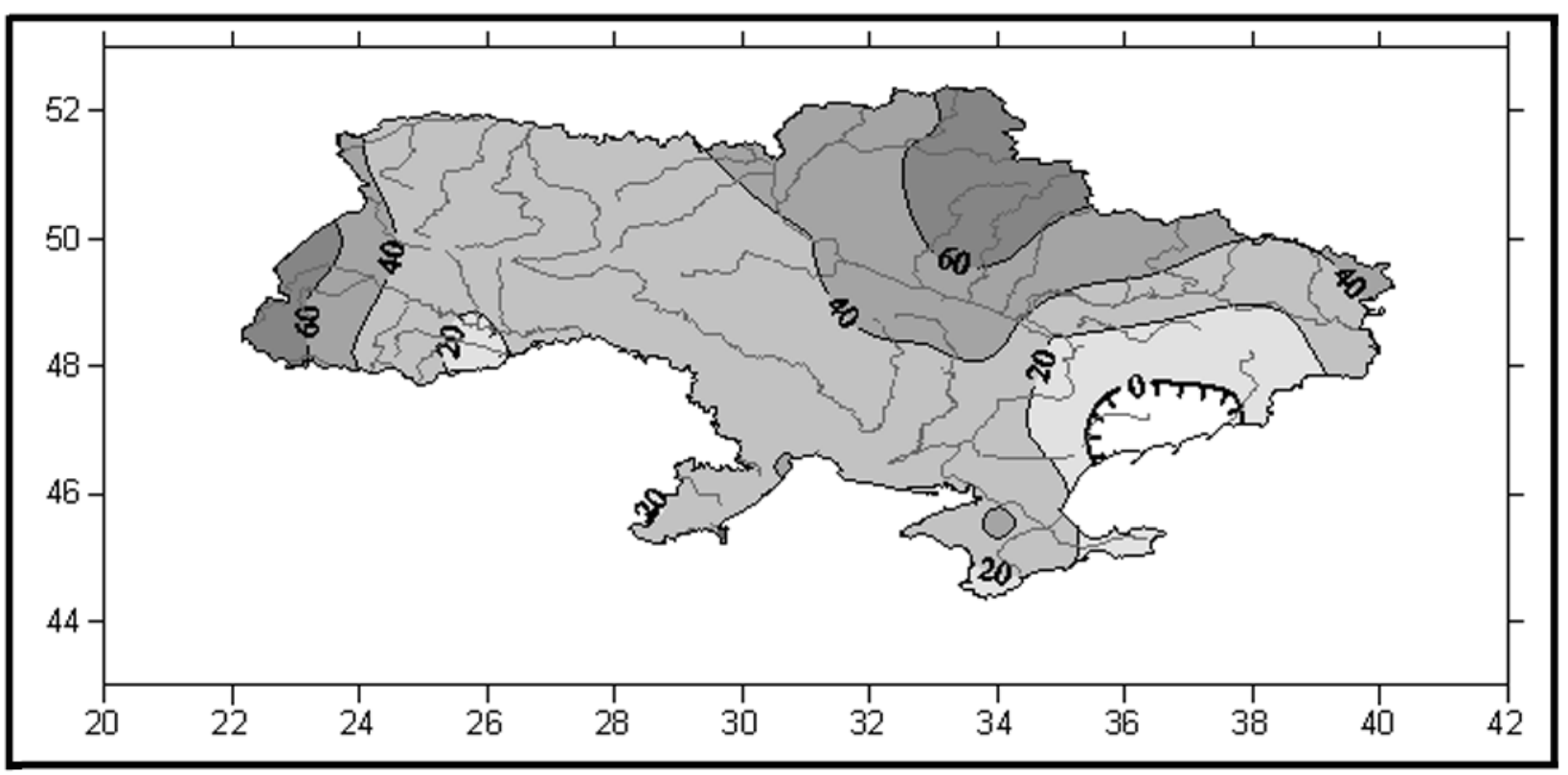

Рисунок 1. Відхилення тривалості сонячного сяйва (год) у серпні 2001 р. відносно 1961-1990 рр.

У 2006, 2007 і 2009 рр. вони спостерігались на півдні та південному сході країни. Найінтенсивніші засухи відмічались у 2001, 2003, 2010 рр. протягом декількох періодів навесні, влітку і восени, що призводило до масового погіршення стану або загибелі сількогосподарських культур. Так, повітряно-грунтова засуха у липні-серпні 2001 р. простежувалась на більшій частині території 3 максимальною температурою повітря до $40^{\circ} \mathrm{C}$ і відносною вологістю менше $30 \%$. У вересні засуху було зареєстровано на південному сході. У липні-серпні 2001 p. відмічалось значне збільшення тривалості сонячного сяйва на всій території. На рис.1 представлено відхилення тривалості сонячного сяйва у серпні 2001 р. відносно 1961-1990 pp.

Істотне збільшення тривалості сонячного сяйва відмічалося для всієї території, найбільше - на північному сході, а також в районі Закарпатської низовини і Українських Карпат, найменші відхилення - на південному сході країни. У період липня-серпня 2001 р. визначено зміни у надходженні прямої, розсіяної й сумарної сонячної радіації, альбедо та радіаційного балансу підстильної поверхні порівняно 3 кліматологічною стандартною нормою 1961-1990 pр.

У табл. 1 наведено порівняння складових радіаційного балансу у серпні 2001 р. відносно норми 1961-1990 pp.

У серпні 2001р. відбулося значне збільшення прямої сонячної радіації, за винятком центрального Правобережжя і деяких районів південного Степу, де відмічалось їх зниження. Одночасно зменшилась розсіяна радіація. Сумарна радація і радіаційний баланс зросли майже по всій території, починаючи 3 північного сходу на південь. Альбедо підстильної поверхні не зазнало змін на більшості території, але зросло у південному Степу. По всій території країни друга половина активної вегетації була посушливішою порівняно з першою. Істотне зростання прямої радіації, що спостерігалося для більшої частини території у серпні 2001 р., мало здебільшого меридіональний характер відхилення відносно 1961-1990 рр. внаслідок характеру атмосферної циркуляції цього періоду.

Зазвичай, початок весняного сезону характеризується недостатнім атмосферним зволоженням, що послаблюється, або зникає у другій половині квітня. У двох перших декадах травня створюються умови для розвитку атмосферної засухи, яка часто без дощу та нестачі вологи у грунті перетворюється на повітряно-грунтову.

Повітряно-грунтова засуха, що розпочалася 3 другої декади квітня до кінця червня 2003 р., охоплювала більшу частину території, крім західних областей. У вересні спостерігалась грунтова засуха. Температура повітря у весняно-літню засуху перевищувала $30^{\circ} \mathrm{C}$, а період без опадів становив 60-70 днів. Запаси продуктивної вологи у метровому шарі грунту знизились до 25-50 мм, а на окремих площах він був зовсім сухим.

Погіршення стану сільськогосподарських культур до незадовільного відмічалось у більшості центральних областей та у Криму. Спостерігалось пожовтіння, засихання листя та стебел, склалися несприятливі умови для цвітіння рослин та наливання зерна. Продуктивність посівів ранніх ярих зернових культур виявилась надзвичайно низькою.

У травні 2003 р. визначився дещо інший, порівняно 3 серпнем 2001 р., просторовий розподіл складових радіаційного балансу. Ізолінії відхилень складових радіаційного режиму відносно 19611990 рр. наближались до широтних. Істотними 
Таблиця 1. Порівняння (МДж/м²) прямої (S), розсіяної (D), сумарної (Q) радіації, радіаційного балансу (B) і альбедо (\%, A $)$ у серпні 2001 р. відносно 1961-1990 pp.

\begin{tabular}{|c|c|c|c|c|c|}
\hline Період & $\mathrm{S}$ & $\mathrm{D}$ & Q & $A_{k}$ & B \\
\hline \multicolumn{6}{|c|}{ Покошичі } \\
\hline 2001 p. & 329 & 237 & 566 & 22 & 308 \\
\hline 1961-1990 pp. & 251 & 254 & 505 & 23 & 244 \\
\hline Різниця & 78 & -17 & 61 & -1 & 64 \\
\hline \multicolumn{6}{|c|}{ Конотоп } \\
\hline 2001 p. & 400 & 215 & 615 & 19 & 368 \\
\hline 1961-1990 pp. & 261 & 233 & 494 & 19 & 253 \\
\hline Різниця & 139 & -18 & 121 & 0 & 115 \\
\hline \multicolumn{6}{|c|}{ Ковель } \\
\hline 2001 p. & 308 & 240 & 548 & 18 & 248 \\
\hline 1961-1990 pp. & 237 & 238 & 475 & 18 & 179 \\
\hline Різниця & 71 & 2 & 73 & 0 & 69 \\
\hline \multicolumn{6}{|c|}{ Бориспіль } \\
\hline $2001 \mathrm{p}$. & 287 & 245 & 532 & 20 & 242 \\
\hline 1961-1990 pp. & 296 & 255 & 551 & 19 & 270 \\
\hline Різниця & -9 & -10 & -19 & 1 & -28 \\
\hline \multicolumn{6}{|c|}{ Нова Ушиця } \\
\hline 2001 p. & 229 & 185 & 414 & 20 & 177 \\
\hline 1961-1990 pp. & 256 & 235 & 491 & 20 & 237 \\
\hline Різниця & -27 & -50 & -77 & 0 & -60 \\
\hline \multicolumn{6}{|c|}{ Полтава } \\
\hline $2001 \mathrm{p}$. & 417 & 217 & 634 & 20 & 339 \\
\hline 1961-1990 pp. & 326 & 227 & 553 & 20 & 261 \\
\hline Різниця & 91 & -10 & 81 & 0 & 78 \\
\hline \multicolumn{6}{|c|}{ Міжгір'я } \\
\hline $2001 \mathrm{p}$. & 323 & 184 & 506 & 18 & 295 \\
\hline 1961-1990 pp. & 185 & 245 & 430 & 23 & 201 \\
\hline Різниця & 138 & -61 & 76 & -5 & 94 \\
\hline \multicolumn{6}{|c|}{ Берегове } \\
\hline 2001 p. & 342 & 161 & 503 & 20 & 269 \\
\hline 1961-1990 pp. & 264 & 254 & 518 & 20 & 247 \\
\hline Різниця & 78 & -93 & -15 & 0 & 22 \\
\hline \multicolumn{6}{|c|}{ Одеса } \\
\hline 2001 p. & 451 & 187 & 638 & 20 & 240 \\
\hline 1961-1990 pp. & 368 & 233 & 601 & 17 & 295 \\
\hline Різниця & 83 & -46 & 37 & 3 & 55 \\
\hline \multicolumn{6}{|c|}{ Болград } \\
\hline 2001 p. & 349 & 253 & 602 & 21 & 265 \\
\hline 1961-1990 pp. & 353 & 258 & 611 & 18 & 320 \\
\hline Різниця & -4 & -5 & -9 & 3 & -55 \\
\hline \multicolumn{6}{|c|}{ Херсон } \\
\hline 2001 p. & 413 & 192 & 605 & 21 & 259 \\
\hline 1961-1990 pp. & 357 & 250 & 607 & 19 & 286 \\
\hline Різниця & 56 & -58 & -2 & 2 & -27 \\
\hline \multicolumn{6}{|c|}{ Асканія Нова } \\
\hline $2001 \mathrm{p}$. & 349 & 154 & 503 & 20 & 261 \\
\hline 1961-1990 pp. & 342 & 239 & 581 & 18 & 289 \\
\hline Різниця & 7 & -85 & -78 & 2 & -28 \\
\hline \multicolumn{6}{|c|}{ Карадаг } \\
\hline $2001 \mathrm{p}$. & 493 & 192 & 685 & 19 & 284 \\
\hline 1961-1990 pp. & 376 & 232 & 608 & 18 & 293 \\
\hline Різниця & 117 & -40 & 77 & 1 & -9 \\
\hline \multicolumn{6}{|c|}{ Нікітський Сад } \\
\hline $2001 \mathrm{p}$. & 513 & 193 & 706 & 19 & 340 \\
\hline 1961-1990 pp. & 391 & 220 & 611 & 19 & 294 \\
\hline Різниця & 122 & -27 & 95 & 0 & 46 \\
\hline
\end{tabular}




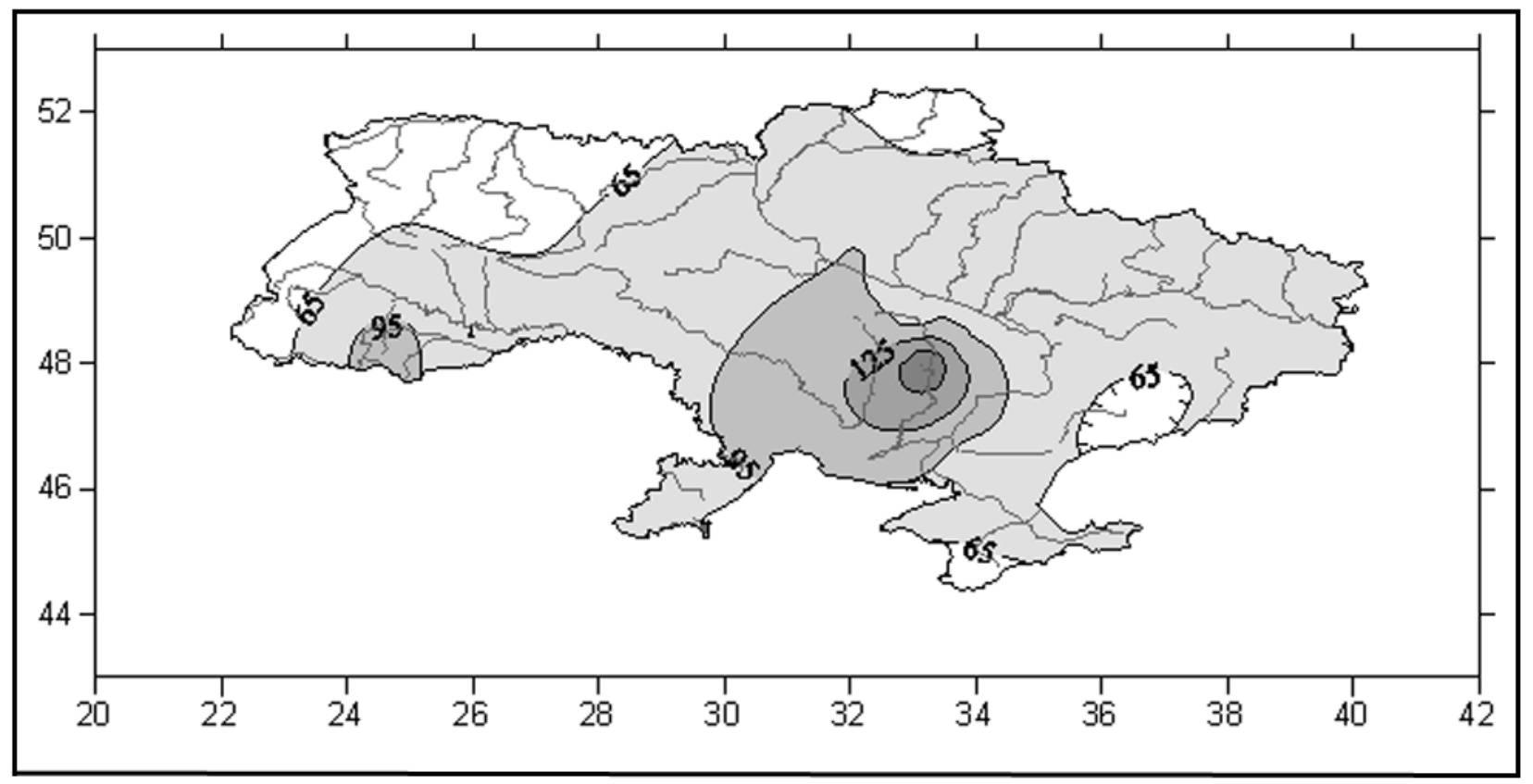

Рисунок 2. Відхилення тривалості сонячного сяйва (год) у травні 2003 р. відносно кліматологічної стандартної норми 1961-1999 рр.

були й зміни тривалості сонячного сяйва у травні 2003 р. порівняно з кліматологічною стандартною нормою 1961-1990 рр. (рис. 2). Збільшення тривалості сонячного сяйва відмічалося по всій теритоpiї, найбільше - у південному Степу. Значне підвищення спостерігалося в районі Українських Карпат і Закарпатської низовини.

Весняно-літня засуха 2003 р., що розпочалася з другої декади квітня до кінця червня і охоплювала більшу частину території (крім західних областей),

Таблиця 2. Відхилення альбедо діяльної поверхні (\%) наприкінці квітня - на початку травня 2003 р. відносно кліматологічної стандартної норми 1961-1990 pp.

\begin{tabular}{|l|c|c|c|}
\hline \multicolumn{1}{|c|}{ Станція } & $\begin{array}{c}\text { Квітень- } \\
\text { травень } \\
2003 \mathrm{p} .\end{array}$ & $\begin{array}{c}1961- \\
1990 \mathrm{pp} .\end{array}$ & Різниця \\
\hline Покошичі & 31 & 23 & 8 \\
\hline Конотоп & 24 & 17 & 7 \\
\hline Ковель & 28 & 18 & 10 \\
\hline Бориспіль & 21 & 17 & 4 \\
\hline Нова Ушиця & 22 & 20 & 2 \\
\hline Полтава & 19 & 18 & 1 \\
\hline Міжгір'я & 29 & 21 & 8 \\
\hline Берегове & 21 & 20 & 1 \\
\hline Одеса & 20 & 18 & 2 \\
\hline Болград & 24 & 19 & 5 \\
\hline Херсон & 21 & 19 & 2 \\
\hline Асканія Нова & 21 & 19 & 2 \\
\hline Карадаг & 20 & 19 & 1 \\
\hline Нікітський Сад & 20 & 19 & 1 \\
\hline Світловодськ & 21 & 18 & 3 \\
\hline
\end{tabular}

характеризувалась як повітряно-грунтова, вона істотно впливала на стан підстильної поверхні внаслідок висихання грунту. Гідротермічний коефіцієнт у Степу і Лісостепу подекуди становив 0,1-0,2.

Найбільші зміни були притаманні прямій сонячній радіації, яка збільшилась на 25-85 \% відносно норми на всій території. Відбулося зменшення розсіяної радіації і підвищення сумарної. У зв'язку зі зміною стану підстильної поверхні, підсиханням та посвітлінням грунту альбедо підстильної поверхні у деяких районах почало зростати. Радіаційний баланс майже для всієї території значно збільшився.

У квітні і на початку травня недостатній розвиток рослин, що не прикривали поверхню грунту, стимулював збільшення відбивної спроможності діяльної поверхні (альбедо). Дещо подібний розподіл альбедо відбувається також під час осінньої засухи у вересні-жовтні, після збирання сільськогосподарських культур, коли підстильна поверхня являє собою сухий оголений грунт. Відчутні зміни складових радіаційного балансу спостерігались наприкінці квітня - на початку травня 2003 р. внаслідок зміни стану підстильної поверхні, що зумовлювало умови для відбиття сумарної радіації, формування зменшених сум балансу короткохвильової радіації та збільшення ефективного випромінювання підстильної поверхні, а це, в свою чергу, спричинювало перетворення значень радіаційного балансу.

Значне відхилення альбедо діяльної поверхні реєструвалося наприкінці квітня - на початку травня 2003 р. відносно кліматологічної стандартної норми 1961-1990 рр. (табл. 2). 


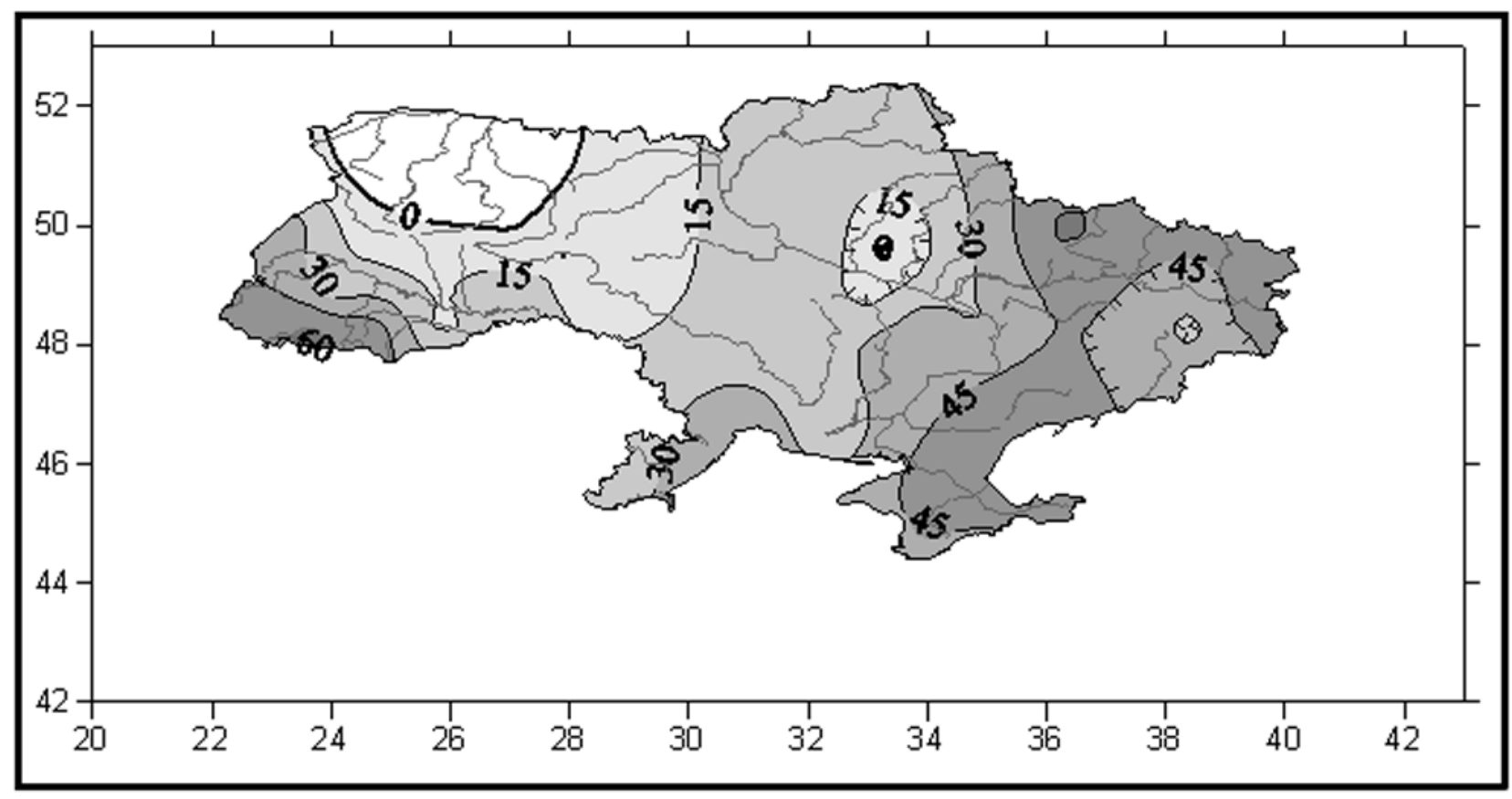

Рисунок 3. Відхилення тривалості сонячного сяйва (год) у серпні 2010 р. відносно 1961-1990

Найбільші відхилення альбедо вимірювались на півночі країни, що є свідченням істотної зміни стану підстильної поверхні і розповсюдження засухи з цього напрямку.

Досить схожі умови розвитку атмосферної засухи липня-серпня 2001 р. спостерігались також у період атмосферно-грунтової засухи у липнісерпні 2010 р., коли було виявлено три іiі періоди. Перший розпочався з квітня і тривав до першої декади травня, другий - у червні, третій - з середини липня до кінця серпня. У липні-серпні фіксувалась відсутність атмосферних опадів, максимальна температура повітря становила $38-42{ }^{\circ} \mathrm{C}$, температура грунту на глибині $10 \mathrm{~cm}-$ до $25-33^{\circ} \mathrm{C}$, відносна вологість зменшувалась до 30 \% і нижче.

За розрахунками, гідротермічний коефіцієнт (ГТК) у Степу і Лісостепу у періоди інтенсивної засухи подекуди становив до $0,1-0,2$, а засуха характеризувалась як повітряно-грунтова.

Досить значним було підвищення тривалості сонячного сяйва у серпні 2010 р. по території. Про це свідчить відхилення тривалості сонячного сяйва відносно норми 1961-1990 pр. (рис. 3).

Відхилення тривалості сонячного сяйва по території було досить нерівномірним. Найбільші позитивні зміни відбувалися на сході і у Криму, в районі Українських Карпат та на Закарпатській низовині. На північному заході спостерігалось невелике зменшення тривалості.

Значне перетворення у надходженні й перерозподілі променистої енергії відбувалось на рівні підстильної поверхні у засушливий період липня
- серпня 2010 р. Реєструвалось здебільшого зростання прямої та сумарної радіації при одночасному зменшенні розсіяної. Найбільше позитивне відхилення прямої і від'ємне розсіяної радіації відмічено в Українських Карпатах. Для більшої частини території спостерігалось зростання альбедо та радіаційного балансу підстильної поверхні. На північному заході та північному сході відмічалось збільшення розсіяної радіації.

Зміна складових радіаційного балансу у серпні 2010 р. відносно норми 1961-1990 рр. представлена у табл. 3 .

Позитивні відхилення прямої радіації у серпні 2010 р. відносно норми 1961-1990 рр. розповсюджувались 3 півночі на південь у широтному напрямку, про що свідчить їх просторовий розподіл (рис. 4).

Деяка неузгодженість у розподілі відхилення тривалості сонячного сяйва (рис. 3) і прямої радіації (рис. 4) по території є результатом значної розбіжності у використанні різної кількості станцій для картографування цих величин.

\section{Висновки}

Явище засухи зумовлюється особливим станом атмосфери 3 антициклональним характером атмосферних процесів та тривалою трансформацією малорухомих повітряних мас на великих територіях. Складний комплекс динамічних процесів, що призводить до розвитку цього явища, пов'язаний 3 підвищеним надходженням інсоляції, високою температурою за бездощовим періодом.

В умовах засухи відбувається реформування 
Таблиця 3. Порівняння (МДж/м ${ }^{2}$ ) прямої (S), розсіяної (D), сумарної (Q) радіації, радіаційного балансу (B) і альбедо (\%, A $)$ у серпні 2010 р. відносно 1961-1990 pp.

\begin{tabular}{|c|c|c|c|c|c|}
\hline Період & $\mathrm{S}$ & $\mathrm{D}$ & $\mathrm{Q}$ & $A_{k}$ & $\mathrm{~B}$ \\
\hline \multicolumn{6}{|c|}{ Покошичі } \\
\hline 2010 p. & 252 & 304 & 556 & 23 & 219 \\
\hline 1961-1990 pp. & 251 & 254 & 505 & 23 & 244 \\
\hline Різниця & 1 & 50 & 51 & 0 & -25 \\
\hline \multicolumn{6}{|c|}{ Конотоп } \\
\hline 2010 p. & 335 & 255 & 590 & 17 & 346 \\
\hline 1961-1990 pp. & 261 & 233 & 494 & 19 & 253 \\
\hline Різниця & 74 & 22 & 96 & -2 & 93 \\
\hline \multicolumn{6}{|c|}{ Ковель } \\
\hline 2010 p. & 227 & 262 & 489 & 18 & 229 \\
\hline 1961-1990 pp. & 237 & 238 & 475 & 18 & 179 \\
\hline Різниця & -10 & 24 & 14 & 0 & 50 \\
\hline \multicolumn{6}{|c|}{ Бориспіль } \\
\hline 2010 p. & 285 & 248 & 533 & 20 & 250 \\
\hline 1961-1990 pp. & 296 & 255 & 551 & 19 & 270 \\
\hline Різниця & -11 & -7 & -18 & 1 & -20 \\
\hline \multicolumn{6}{|c|}{ Нова Ушиця } \\
\hline $2010 \mathrm{p}$. & 266 & 233 & 499 & 21 & - \\
\hline 1961-1990 pp. & 256 & 235 & 491 & 20 & 237 \\
\hline Різниця & 10 & -2 & 8 & 1 & - \\
\hline \multicolumn{6}{|c|}{ Полтава } \\
\hline $2010 \mathrm{p}$. & 372 & 230 & 602 & 21 & 365 \\
\hline 1961-1990 pp. & 326 & 227 & 553 & 20 & 261 \\
\hline Різниця & 46 & 3 & 49 & 1 & 104 \\
\hline \multicolumn{6}{|c|}{ Міжгір'я } \\
\hline 2010 p. & 295 & 157 & 452 & 20 & 248 \\
\hline 1961-1990 pp. & 185 & 245 & 430 & 23 & 201 \\
\hline Різниця & 110 & -88 & 22 & -3 & 47 \\
\hline \multicolumn{6}{|c|}{ Берегове } \\
\hline 2010 p. & 281 & 207 & 488 & 20 & 262 \\
\hline 1961-1990 pp. & 264 & 254 & 518 & 20 & 247 \\
\hline Різниця & 17 & -47 & 30 & 0 & 15 \\
\hline \multicolumn{6}{|c|}{ Одеса } \\
\hline 2010 p. & 450 & 207 & 657 & 18 & 309 \\
\hline 1961-1990 pp. & 368 & 233 & 601 & 17 & 295 \\
\hline Різниця & 82 & -26 & 56 & 1 & 14 \\
\hline \multicolumn{6}{|c|}{ Болград } \\
\hline $2010 \mathrm{p}$. & 402 & 203 & 605 & 19 & 349 \\
\hline 1961-1990 pp. & 353 & 258 & 611 & 18 & 320 \\
\hline Різниця & 49 & -55 & -6 & 1 & 29 \\
\hline \multicolumn{6}{|c|}{ Херсон } \\
\hline $2010 \mathrm{p}$. & 439 & 219 & 658 & 22 & 269 \\
\hline 1961-1990 pp. & 357 & 250 & 607 & 19 & 286 \\
\hline Різниця & 82 & -31 & 51 & 3 & -17 \\
\hline \multicolumn{6}{|c|}{ Асканія Нова } \\
\hline 2010 p. & 444 & 191 & 635 & 20 & 314 \\
\hline 1961-1990 pp. & 342 & 239 & 581 & 18 & 289 \\
\hline Різниця & 102 & -48 & 54 & 2 & 25 \\
\hline \multicolumn{6}{|c|}{ Карадаг } \\
\hline $2010 \mathrm{p}$. & 514 & 195 & 709 & 22 & 332 \\
\hline 1961-1990 pp. & 376 & 232 & 608 & 18 & 293 \\
\hline Різниця & 138 & -37 & 101 & 4 & 39 \\
\hline \multicolumn{6}{|c|}{ Нікітський Сад } \\
\hline $2010 \mathrm{p}$. & 481 & 185 & 666 & 20 & 301 \\
\hline $1961-1990 \mathrm{pp}$. & 391 & 220 & 611 & 19 & 294 \\
\hline Різниця & 90 & -35 & 55 & 1 & 7 \\
\hline
\end{tabular}




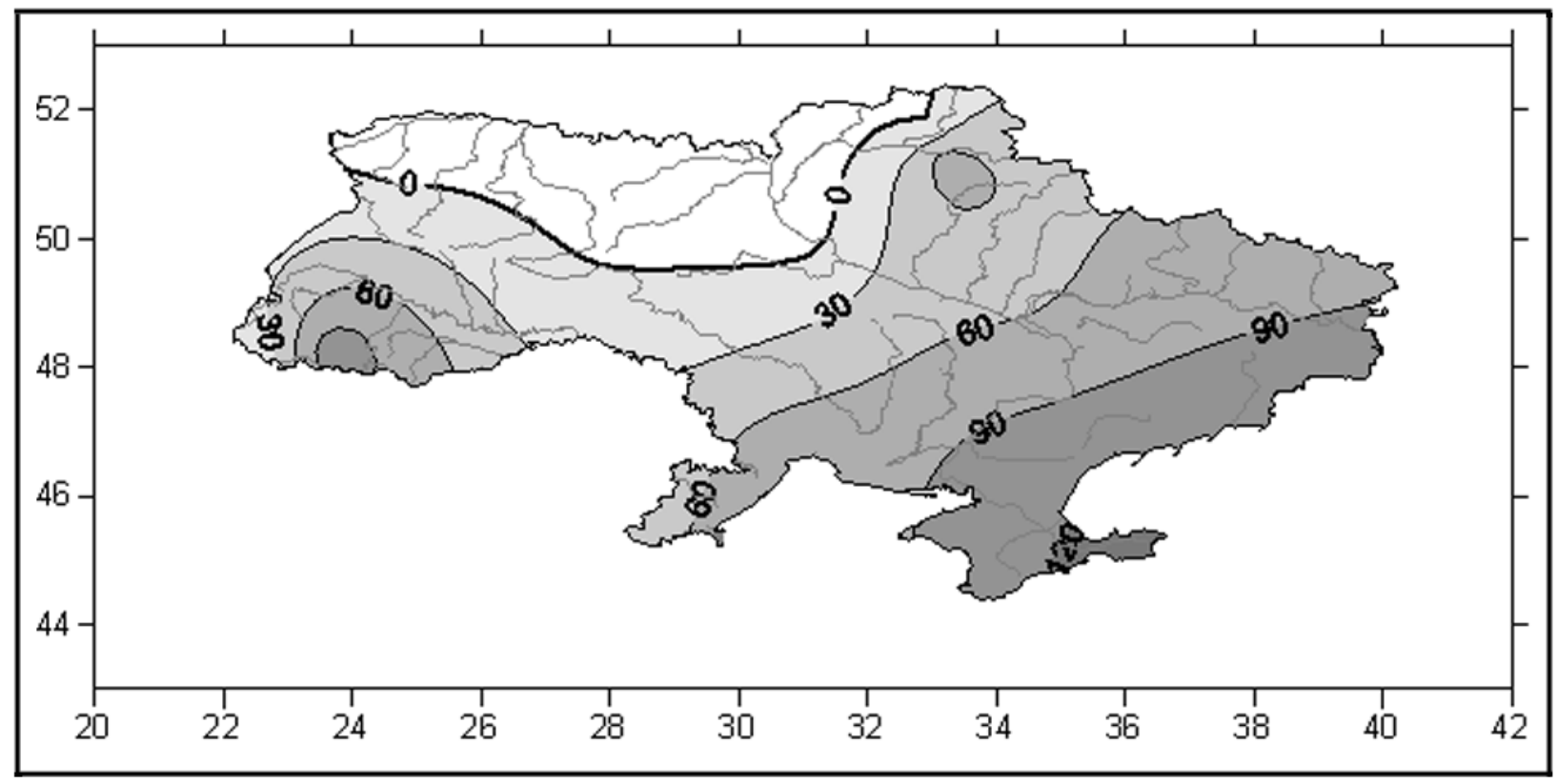

Рисунок 4. Відхилення прямої радіації (МДж/м²) у серпні 2010 р. відносно 1961-1990 pр.

тривалості сонячного сяйва, прямої, розсіяної та сумарної сонячної радіаціїі, альбедо і радіаційного балансу підстильної поверхні.

Значна зміна стану підстильної поверхні у періоди весняних і осінніх засух, за часто оголеного грунту, призводить до відчутних коливань відбивної спроможності підстильної поверхні (альбедо).

Істотне підвищення надходження прямої радіації і тривалості сонячного сяйва, за умови зміни стану підстильної поверхні, спричинює коливання у формуванні балансу короткохвильової радіації (поглинута радіація), ефективного випромінювання та повного радіаційного балансу.

У вегетаційний період, за середніх умов, $60 \%$ радіаційного балансу витрачається на випаро- вування, $30 \%$ - на турбулентний обмін повітря у нижніх шарах атмосфери і $10 \%$ - на нагрівання грунту.

Розвиток засухи зумовлює перерозподіл витратної частини радіаційного балансу. Витрати тепла на випаровування в окремі періоди зменшуються до $40 \%$, а іноді до $30 \%$. Витрати тепла на турбулетний обмін зростають до $50 \%$ і більше. За умов тривалої бездощової погоди і високої температури повітря $\left(35-40{ }^{\circ} \mathrm{C}\right)$ на нагрівання приземного шару повітря витрачається до $70 \%$ радіаційного балансу.

Дослідження цих явищ має важливе науковотеоретичне, а також практичне значення для вирішення питань адаптації землеробства до змінюваних агрокліматичних умов.

\section{Лimepamypa}

1. Дмитренко В.П., Строкач Н.К. Посушливі явища (Бездощовий період, суховій, посуха) // Клімат України. За ред. В.М.Ліпінського, В.А.Дячука, В.М.Бабіченко. - К.: Вид-во Раєвського, 2003. - С. 233-245.

2. Дмитренко В.П. Посушливі явища // Погода, клімат і урожай польових культур.- К.: Ніка-Центр, 2010. - С. 328-336.

3. Логвинов К.Т., Сакали Л.И., Дайгот Л.С. Оценка степени засушливости вегетационного перида // Особенности засухи 1972 г. на Украине. - Л.: Гидрометеоиздат, 1973. - С. 25-29.

4. Мартазинова В.Ф., Свердлик Т.А. Крупномастабная атмосферная циркуляция ХХ столетия, ее изменение и современное состояние // Тр. УкрНИГМИ. - 1998. - Вып. 246. - С. 21-27.

5. Мартазинова В.Ф., Сологуб Т.А. Атмосферная циркуляция, формирующая засушливые условия на территории Украины в конце ХХ столетия // Наук. праці УкрНДГМІ. - 2000. - Вип. 248. - С. 36-47.

6. Рибченко Л.С. Перетворення радіаційного режиму у період посухи // Вісник Київ. нац. ун-ту. ім. Тараса Шевченка. Фізична географія та геоморфологія. - 2006. - Вип. 50. - С. 134-139.

7. Рибченко Л.С. Зміна радіаційного режиму в умовах сучасної посухи в Україні // Укр. геогр. журн. - 2007. - № 1. - С. 14-19.

8. Характер изменения среднесуточной температуры воздуха на территории Украины в последние десятилетия и физикостатистический метод его прогноза с длительной заблаговременностью / В.Ф. Мартазинова, В.В. Остапчук, Е.К. Иванова, В.М. Прохоренко // Тр. УкрНИГМИ. - 1999. - Вып. 247. - С. 36-48. 